\title{
Facile and Efficient Synthesis of $\left[{ }^{18}\right.$ F $]$ Fluoromisonidazole Using Novel 2-Nitroimidazole Derivatives
}

\author{
Young-Do Kwon, ${ }^{a}$ Yongju Jung, ${ }^{b}$ Seok Tae Lim, ${ }^{a}$ Myung-Hee Sohn ${ }^{a}$ and \\ Hee-Kwon Kim $* a$
}

\begin{abstract}
${ }^{a}$ Department of Nuclear Medicine, Molecular Imaging \& Therapeutic Medicine Research Center, Biomedical Research Institute, Chonbuk National University Medical School and Hospital, Jeonju, 561-712 Jeonbuk, Republic of Korea
\end{abstract}

${ }^{b}$ Department of Chemical Engineering, Korea University of Technology and Education, 330-708 Cheonan, Republic of Korea

\begin{abstract}
$\left[{ }^{18} \mathrm{~F}\right]$ Fluoromisonidazole $\left(\left[{ }^{18} \mathrm{~F}\right] \mathrm{FMISO}\right)$ is a hypoxia imaging marker utilized in positron emission tomography. Novel FMISO precursors were prepared from a commercially available material, and several reaction factors that affect synthesis of $\left[{ }^{18} \mathrm{~F}\right] \mathrm{FMISO}$ were examined to achieve a higher fluorination yield. $\left[{ }^{18} \mathrm{~F}\right] \mathrm{FMISO}$ was obtained from radiosynthesis, followed by the hydrolysis of protecting groups with $\mathrm{HCl}$. New 2-nitroimidazole precursor showed a higher $\left[{ }^{18} \mathrm{~F}\right]$ fluorination and a higher synthetic yield. This result provided alternative guidelines for the preparation of hypoxia imaging marker.
\end{abstract}

Keywords: $\left[{ }^{18} \mathrm{~F}\right] \mathrm{FMISO}$, radiosynthesis, fluorine-18, one-pot synthesis, positron emission tomography

\section{Introduction}

Hypoxia, the modality of oxygen deficiency due to inefficiently organized tumor vasculature, is one of characteristics of solid tumors. ${ }^{1}$ Tissue hypoxia is relevant to poor prognosis and difficulty of tumor therapy due to the development of chemo resistance, radio resistance, invasiveness, and metastasis. ${ }^{2,3}$ Due to these features, identification and quantitative assessment of tissue hypoxia is a significant factor for optimal therapy outcome. ${ }^{4}$

Diverse invasive and non-invasive methods using various modalities are available to measure hypoxia in tumors. ${ }^{5}$ Despite many invasive techniques available to assess tissue hypoxia, there are some limitations such as technical complexity, erratic results and impossibility of repetitive measurements. Therefore, non-invasive methods have received attention for routine clinical use in hospitals. ${ }^{6}$ Positron emission tomography (PET) is a promising technique among the non-invasive modalities due to its higher sensitivity and quantification of relative and absolute values over time. ${ }^{7.8}{ }^{18} \mathrm{~F}$ is available for use in PET, due to emission of a positron that produces gamma ray photons through an annihilation event. ${ }^{8}$ High resolution images of PET are obtained by ${ }^{18} \mathrm{~F}$ that has ideal physical properties such as a half-life of $110 \mathrm{~min}$ and a low-energy positron of $640 \mathrm{keV}^{4}$

Nitroimidazole is generally employed and studied as an exogenous marker for tumor hypoxia, due to its unique property in hypoxic environments related to the reduction of its nitro group. ${ }^{9-13}$ Reactive intermediates that accumulate in hypoxic tissues through binding to cellular constituents are generated by a reversible reduction step in normoxic cells but not hypoxic cells. ${ }^{1,14}$ Therefore, nitroimidazole derivatives with ${ }^{18} \mathrm{~F}$ are used to quantify hypoxia through PET. ${ }^{15-18}$ Among the derivatives, $\left[{ }^{18} \mathrm{~F}\right]$ fluoromisonidazole $\left(\left[{ }^{8} \mathrm{~F}\right] \mathrm{FMISO}\right)$ is widely known and studied by many medical groups. ${ }^{14,19-23}$

We were interested in developing a useful method for the synthesis of $\left[{ }^{18} \mathrm{~F}\right] \mathrm{FMISO}$ for higher overall synthetic yield along with a higher radio synthetic yield. Herein, we performed synthesis of $\left[{ }^{18} \mathrm{~F}\right] \mathrm{FMISO}$ using 2-nitroimidazole derivatives as new precursors of $\left[{ }^{18} \mathrm{~F}\right] \mathrm{FMISO}$ and various reaction conditions for the radiosynthesis of $\left[{ }^{18} \mathrm{~F}\right] \mathrm{FMISO}$ were investigated.

*e-mail: hkkim717@jbnu.ac.kr 


\section{Experimental}

\section{General procedure}

All chemicals were purchased from Sigma-Aldrich and used without further purification. The ${ }^{1} \mathrm{H}$ and ${ }^{13} \mathrm{C}$ nuclear magnetic resonance (NMR) spectra were recorded on a $600 \mathrm{MHz}$ spectrometer at room temperature. The chemical shifts were reported in $\delta$ units (ppm) relative to tetramethylsilane (TMS) and the coupling constants $(J)$ quoted in Hz. Reaction progress was monitored by thin-layer chromatography (TLC) analysis. TLC analysis was performed using an aluminum plate with silica gel $60 \mathrm{~F}_{254}$ and TLC spots were visualized by UV light (254 nm) exposure. Flash chromatography was performed using 230-400 mesh silica gel and analytical grade solvent. Electrospray ionization (ESI) high resolution mass spectrometry (HRMS) was performed by Mass Spectrometry Service of Chonbuk National University and Korea Basic Science Institute. $\left[{ }^{18} \mathrm{~F}\right]$ Fluoride was produced using a cyclotron (Kirams-13 Cyclone, South Korea) by the ${ }^{18} \mathrm{O}(\mathrm{p}, \mathrm{n}){ }^{18} \mathrm{~F}$ nuclear reaction. Typically, $\left[{ }^{18} \mathrm{~F}\right]$ fluoride was obtained via irradiation of $0.8 \mathrm{~mL}$ of $98 \%$ enriched ${ }^{18} \mathrm{O}$-enriched water with a $13 \mathrm{MeV}$ proton beam for 40-50 min. Radioactivity was determined using a calibrated ion chamber (Capintec CRC-15R).

Synthesis of (2,2-dimethyl-1,3-dioxolan-4-yl)methyl 4-methylbenzenesulfonate (2)

(2,2-Dimethyl-1,3-dioxolan-4-yl)methanol (7.37 g, $55.8 \mathrm{mmol})$ and triethylamine $(20.15 \mathrm{~g}, 199 \mathrm{mmol})$ were dissolved in anhydrous $\mathrm{CH}_{2} \mathrm{Cl}_{2}(40 \mathrm{~mL})$. $p$-Toluenesulfonyl chloride (14.6 g, $77.0 \mathrm{mmol})$ was added dropwise to the mixture at $0{ }^{\circ} \mathrm{C}$. The mixture was stirred at room temperature for $9 \mathrm{~h} 30 \mathrm{~min}$. The crude product was extracted with $\mathrm{CH}_{2} \mathrm{Cl}_{2}(100 \mathrm{~mL})$ from water and re-extracted with ethyl acetate $(100 \mathrm{~mL})$. The combined extracts were dried with $\mathrm{Na}_{2} \mathrm{SO}_{4}$ and filtered. The filtrate was concentrated under reduced pressure, and then purified by flash column chromatography (EtOAc:hexane $=1: 5$ ) on silica gel to afford compound 2 $(15.3 \mathrm{~g}, 95.9 \%)$ as a white solid. ${ }^{1} \mathrm{H} \mathrm{NMR}(600 \mathrm{MHz}$, $\left.\mathrm{CDCl}_{3}\right) \delta 7.80(\mathrm{~d}, 2 \mathrm{H}, J 8.4 \mathrm{~Hz}, \mathrm{Ar}-\mathrm{H}), 7.36(\mathrm{~d}, 2 \mathrm{H}$, $J$ 7.8 Hz, Ar-H), 4.30-4.26 (m, 1H, CH), 4.05-3.97 (m, $3 \mathrm{H}, 2 \mathrm{CH}_{2}$ and $\left.1 \mathrm{H}, \mathrm{CH}_{2}\right), 3.77(\mathrm{dd}, 1 \mathrm{H}, J 9.0,4.8 \mathrm{~Hz}$, $\left.\mathrm{CH}_{2}\right), 2.45\left(\mathrm{~s}, 3 \mathrm{H}, \mathrm{CH}_{3}\right), 1.34\left(\mathrm{~s}, 3 \mathrm{H}, \mathrm{CH}_{3}\right), 1.31$ (s, $\left.3 \mathrm{H}, \mathrm{CH}_{3}\right) ;{ }^{13} \mathrm{C} \mathrm{NMR}\left(150 \mathrm{MHz}, \mathrm{CDCl}_{3}\right) \delta 145.2,132.7$, 130.0, 128.1, 110.1, 73.0, 69.6, 66.2, 26.7, 25.2, 21.7; HRMS (ESI) calcd. for $\mathrm{C}_{13} \mathrm{H}_{18} \mathrm{O}_{5} \mathrm{~S}[\mathrm{M}+\mathrm{H}]^{+}:$286.0875; found: 286.0912
Synthesis of 1-((2,2-dimethyl-1,3-dioxolan-4-yl)methyl)-2nitro- $1 \mathrm{H}$-imidazole (3)

2-Nitroimidazole (1.42 g, $12.57 \mathrm{mmol})$ and cesium carbonate $(3.75 \mathrm{~g}, 11.52 \mathrm{mmol})$ were added to a solution of compound 2 (3 g, $10.48 \mathrm{mmol})$ in anhydrous $N, N$-dimethylformamide (DMF) $(18 \mathrm{~mL})$. The mixture was stirred at $110{ }^{\circ} \mathrm{C}$ for $12 \mathrm{~h}$. The reaction mixture was then cooled and extracted with ethyl acetate $(100 \mathrm{~mL})$. The extract was dried over $\mathrm{Na}_{2} \mathrm{SO}_{4}$ and filtered. The filtrate was concentrated under reduced pressure and then purified by flash column chromatography (EtOAc:hexane =1:1) on silica gel to yield compound $3(1.96 \mathrm{~g}, 82.4 \%)$ as a yellowish oil. ${ }^{1} \mathrm{H}$ NMR (600 MHz, $\left.\mathrm{CDCl}_{3}\right) \delta 7.27$ (s, 1H, Im-H*), 7.19 (s, 1H, Im-H), 4.74 (dd, 1H, J 13.8, 2.4 Hz, $\mathrm{CH}_{2}$ ), 4.50-4.46 (m, 1H, CH), 4.41 (dd, 1H, J 13.8, 7.2 Hz, $\mathrm{CH}_{2}$ ), 4.19 (dd, $1 \mathrm{H}, J$ 8.4, $6.0 \mathrm{~Hz}, \mathrm{CH}_{2}$ ), 3.70 (dd, $\left.1 \mathrm{H}, J 9.0,5.4 \mathrm{~Hz}, \mathrm{CH}_{2}\right)$, 1.43 (s, 3H, $\left.\mathrm{CH}_{3}\right), 1.37$ (s, 3H, $\left.\mathrm{CH}_{3}\right) ;{ }^{13} \mathrm{C} \mathrm{NMR}(150 \mathrm{MHz}$, $\left.\mathrm{CDCl}_{3}\right) \delta 144.9,128.2,127.3,110.4,74.0,66.4,52.1,26.6$, 25.2; HRMS (ESI) calcd. for $\mathrm{C}_{9} \mathrm{H}_{13} \mathrm{~N}_{3} \mathrm{O}_{4}[\mathrm{M}+\mathrm{H}]^{+}$: 227.0906 ; found: 227.0857 . *Im-H: imidazole hydrogens.

\section{Synthesis of compound $\mathbf{3}$ from compound $\mathbf{1}$}

(2,2-Dimethyl-1,3-dioxolan-4-yl)methanol (0.271 g, $2.06 \mathrm{mmol})$ and triethyl amine $(0.62 \mathrm{~g}, 6.13 \mathrm{mmol})$ were dissolved in anhydrous $\mathrm{CH}_{2} \mathrm{Cl}_{2}(2 \mathrm{~mL})$. $p$-Toluenesulfonyl chloride $(0.59 \mathrm{~g}, 3.11 \mathrm{mmol})$ was added dropwise to the mixture. After the mixture was stirred at room temperature for $8 \mathrm{~h}, 2$-nitroimidazole $(0.35 \mathrm{~g}, 3.09 \mathrm{mmol})$, cesium carbonate ( $1 \mathrm{~g}, 3.08 \mathrm{mmol})$ and anhydrous DMF $(2 \mathrm{~mL})$ were added to the reaction mixture. The reaction mixture was stirred at $110{ }^{\circ} \mathrm{C}$ for $12 \mathrm{~h}$. The crude product was extracted with $\mathrm{CH}_{2} \mathrm{Cl}_{2}(20 \mathrm{~mL})$ and dried over $\mathrm{Na}_{2} \mathrm{SO}_{4}$. The solvent was removed under reduced pressure and the residue was purified by flash column chromatography (EtOAc:hexane $=1: 1$ ) on silica gel to yield compound $\mathbf{3}$ $(0.327 \mathrm{~g}, 69.9 \%)$ as a yellowish oil.

Synthesis of 3-(2-nitro-1 H-imidazol-1-yl)propane-1,2-diol (4)

Trifluoroacetic acid $(32.7 \mathrm{~g}, 287.4 \mathrm{mmol})$ was added to a solution of compound $\mathbf{3}$ (4.64 g, $20.4 \mathrm{mmol})$ in anhydrous $\mathrm{MeOH}(20 \mathrm{~mL})$ and stirred at room temperature for $8 \mathrm{~h}$. The solvent was removed under reduced pressure. The residue was purified by flash column chromatography $\left(\mathrm{CH}_{2} \mathrm{Cl}_{2}: \mathrm{MeOH}=10: 1\right)$ on silica gel to afford compound 4 (3.441 g, 90\%) as a yellowish solid. ${ }^{1} \mathrm{H}$ NMR $(600 \mathrm{MHz}$, $\left.\mathrm{CD}_{3} \mathrm{OD}\right) \delta 7.47$ (s, 1H, Im-H), 7.15 (s, 1H, Im-H), 4.76 (dd, $\left.1 \mathrm{H}, J 13.2,3.0 \mathrm{~Hz}, \mathrm{CH}_{2}\right), 4.39$ (dd, $\left.1 \mathrm{H}, J 13.8,9.0 \mathrm{~Hz}, \mathrm{CH}_{2}\right)$, 3.98-3.94 (m, 1H, C트), 3.61-3.54 (m, 2H, $\left.\mathrm{CH}_{2} \mathrm{OH}\right)$; ${ }^{13} \mathrm{C}$ NMR (150 MHz, CD $\left.\mathrm{OD}\right) \delta 145.1,128.0,126.8,70.3$, 63.4, 52.3; HRMS (ESI) calcd. for $\mathrm{C}_{6} \mathrm{H}_{9} \mathrm{~N}_{3} \mathrm{O}_{4}[\mathrm{M}+\mathrm{H}]^{+}$: 187.0593; found: 187.0430 . 
Synthesis of 2-(tert-butyldimethylsilyloxy)-3-(2-nitro-1 $\mathrm{H}$ imidazol-1-yl)propyl 4-methylbenzenesulfonate (5)

p-Toluenesulfonyl chloride $(0.204 \mathrm{~g}, 1.065 \mathrm{mmol})$ was added dropwise to a solution of compound $4(0.21 \mathrm{~g}$, $1.12 \mathrm{mmol})$ in anhydrous pyridine $(2 \mathrm{~mL})$ at $0{ }^{\circ} \mathrm{C}$. The mixture was stirred at room temperature for $6 \mathrm{~h}$. Then imidazole $(0.3 \mathrm{~g}, 4.47 \mathrm{mmol})$ in $\mathrm{CH}_{2} \mathrm{Cl}_{2}(10 \mathrm{~mL})$ was added. After addition of tert-butyldimethylsilyl chloride (0.51 g, $3.36 \mathrm{mmol})$ in $\mathrm{CH}_{2} \mathrm{Cl}_{2}(10 \mathrm{~mL})$ to the mixture, the mixture was stirred at room temperature for $2 \mathrm{~h}$. The mixture was extracted with ethyl acetate $(20 \mathrm{~mL})$ and the extract was dried over $\mathrm{Na}_{2} \mathrm{SO}_{4}$ and filtered. The filtrate was concentrated under reduced pressure, and residual crude product was purified by flash column chromatography (EtOAc:hexane $=1: 2$ ) on silica gel to yield compound $\mathbf{5}$ $(0.334 \mathrm{~g}, 65.53 \%)$ as a white solid. ${ }^{1} \mathrm{H}$ NMR $(600 \mathrm{MHz}$, $\left.\mathrm{CDCl}_{3}\right) \delta 7.71(\mathrm{~d}, 2 \mathrm{H}, J 8.4 \mathrm{~Hz}, \mathrm{Ar}-\mathrm{H}), 7.28(\mathrm{~d}, 2 \mathrm{H}$, $J 7.8 \mathrm{~Hz}, \mathrm{Ar}-\mathrm{H}), 7.02$ (s, 1H, Im-H), 6.98 (s, 1H, Im-H), 4.58 (dd, $1 \mathrm{H}, J 13.8,3.0 \mathrm{~Hz}, \mathrm{CH}_{2}$ ), 4.19 (dd, $1 \mathrm{H}, J 12.6$, $\left.7.2 \mathrm{~Hz}, \mathrm{CH}_{2}\right), 4.13-4.11(\mathrm{~m}, 1 \mathrm{H}, \mathrm{CH}), 3.92(\mathrm{dd}, 1 \mathrm{H}$, $\left.J 10.2,3.6 \mathrm{~Hz}, \mathrm{CH}_{2}\right), 3.82\left(\mathrm{dd}, 1 \mathrm{H}, J 10.2,5.4 \mathrm{~Hz}, \mathrm{CH}_{2}\right.$ ), 2.37 (s, 3H, $\left.\mathrm{CH}_{3}\right), 0.67$ (s, 9H, $\left.\mathrm{CH}_{3}\right),-0.21\left(\mathrm{~s}, 3 \mathrm{H}, \mathrm{CH}_{3}\right.$ ), $-0.41\left(\mathrm{~s}, 3 \mathrm{H}, \mathrm{CH}_{3}\right) ;{ }^{13} \mathrm{C} \mathrm{NMR}\left(150 \mathrm{MHz}, \mathrm{CDCl}_{3}\right) \delta 145.5$, $144.8,132.3,130.2,128.2,128.1,127.7,69.9,68.6,52.7$, 25.6, 21.8, 17.8, -5.12, -5.66; HRMS (ESI) calcd. for $\mathrm{C}_{19} \mathrm{H}_{30} \mathrm{~N}_{3} \mathrm{O}_{6} \mathrm{SSi}[\mathrm{M}+\mathrm{H}]^{+}$: 456.1625; found: 456.1623 .

Synthesis of 2-hydroxy-3-(2-nitro-1H-imidazol-1-yl)propyl 4-methylbenzenesulfonate (6)

p-Toluenesulfonyl chloride $(0.37 \mathrm{~g}, 1.92 \mathrm{mmol})$ was added to a solution of compound $4(0.37 \mathrm{~g}, 1.96 \mathrm{mmol})$ in anhydrous pyridine $(3 \mathrm{~mL})$. The mixture was stirred at room temperature for $23 \mathrm{~h}$. The mixture was washed with brine $(20 \mathrm{~mL})$ and extracted with ethyl acetate $(20 \mathrm{~mL})$. The extract was dried over $\mathrm{Na}_{2} \mathrm{SO}_{4}$ and filtered. The filtrate was concentrated under reduced pressure, and then purified by flash column chromatography $($ EtOAc:hexane $=1.5: 1)$ on silica gel to yield compound $\mathbf{6}(0.43 \mathrm{~g}, 65 \%)$ as a white solid. ${ }^{1} \mathrm{H}$ NMR $\left(600 \mathrm{MHz}, \mathrm{CD}_{3} \mathrm{OD}\right) \delta 7.79(\mathrm{~d}, 2 \mathrm{H}, J 8.4 \mathrm{~Hz}$, $\mathrm{Ar}-\mathrm{H}), 7.44$ (d, 2H, J 7.2 Hz, Ar-H), 7.36 (s, 1H, Im-H), 7.08 (s, 1H, Im-H), 4.61 (dd, $1 \mathrm{H}, J 13.8,3.0 \mathrm{~Hz}, \mathrm{CH}_{2}$ ), 4.32 (dd, $\left.1 \mathrm{H}, J 13.8,8.4 \mathrm{~Hz}, \mathrm{CH}_{2}\right), 4.09-4.00\left(\mathrm{~m}, 3 \mathrm{H}, 2 \mathrm{CH}_{2}\right.$ and $1 \mathrm{H}, \mathrm{C} \underline{\mathrm{HOH}}), 2.45$ (s, $\left.3 \mathrm{H}, \mathrm{CH}_{3}\right) ;{ }^{13} \mathrm{C} \mathrm{NMR}(150 \mathrm{MHz}$, $\left.\mathrm{CD}_{3} \mathrm{OD}\right) \delta 145.5,132.6,129.8,127.8,126.8,70.8,67.3$, 51.6, 20.2; HRMS (ESI) calcd. for $\mathrm{C}_{13} \mathrm{H}_{16} \mathrm{~N}_{3} \mathrm{O}_{6} \mathrm{~S}[\mathrm{M}+\mathrm{H}]^{+}$: 342.0760; found: 342.0757 .

Synthesis of 2-(1-ethoxyethyl)-3-(2-nitro-1H-imidazol-1-yl) propyl 4-methylbenzenesulfonate (7)

Ethyl vinyl ether $(0.9 \mathrm{~g}, 12.5 \mathrm{mmol})$ was added dropwise to a solution of compound $6(0.2 \mathrm{~g}, 0.586 \mathrm{mmol})$ and pyridinium $p$-toluenesulfonate $(0.05 \mathrm{~g}, 0.199 \mathrm{mmol})$ in anhydrous $\mathrm{CH}_{2} \mathrm{Cl}_{2}(35 \mathrm{~mL})$. The mixture was stirred at room temperature for $4 \mathrm{~h}$. The mixture was washed with brine $(20 \mathrm{~mL})$ and extracted with ethyl acetate $(20 \mathrm{~mL})$. The extract was dried over $\mathrm{Na}_{2} \mathrm{SO}_{4}$ and filtered. The filtrate was concentrated under reduced pressure, and then purified by flash column chromatography (EtOAc:hexane $=1: 1)$ on silica gel to yield compound $7(0.17 \mathrm{~g}, 70.3 \%)$ as a yellowish oil. ${ }^{1} \mathrm{H}$ NMR $\left(600 \mathrm{MHz}, \mathrm{CDCl}_{3}\right) \delta 7.79(\mathrm{~d}$, 2H, J 8.4 Hz, Ar-H), 7.36 (d, 2H, J 7.8 Hz, Ar-H), 7.11 (d, 1H, J 6.6 Hz, Im-H), 7.09 (d, 1H, J $6.0 \mathrm{~Hz}, \mathrm{Im}-\mathrm{H})$, 4.71-4.61 (dd, 2H, J 13.8, 3.6 Hz, $\mathrm{CH}_{2}$ ), 4.44-3.98 (m, $4 \mathrm{H}, 3 \mathrm{CH}_{2}$ and $\left.1 \mathrm{H}, \mathrm{CH}\right), 3.37-3.23\left(\mathrm{~m}, 2 \mathrm{H}, \mathrm{CH}\right.$ and $\left.\mathrm{CH}_{2}\right)$, $2.45\left(\mathrm{~s}, 3 \mathrm{H}, \mathrm{CH}_{3}\right), 1.09-0.94\left(\mathrm{~m}, 6 \mathrm{H}, \mathrm{CH}_{3}\right) ;{ }^{13} \mathrm{C} \mathrm{NMR}$ $\left(150 \mathrm{MHz}, \mathrm{CDCl}_{3}\right) \delta 145.4,144.9,132.3,130.2,128.1$, 128.0, 127.7, 101.3, 72.7, 68.7, 60.9, 50.9, 21.8, 19.5, 15.1; HRMS (ESI) calcd. for $\mathrm{C}_{17} \mathrm{H}_{24} \mathrm{~N}_{3} \mathrm{O}_{7} \mathrm{~S}[\mathrm{M}+\mathrm{H}]^{+}$: 414.1335; found: 414.1331 .

\section{Radiosynthesis of $\left[{ }^{18} \mathrm{~F}\right] \mathrm{FMISO}$}

Kryptofix $_{222}\left(\mathrm{~K}_{222}, 4,7,13,16,21,24\right.$-hexaoxa-1,10diazabicyclo[8.8.8]-hexacosane) $(8 \mathrm{mg}, 21.27 \mu \mathrm{mol})$ and $\mathrm{K}_{2} \mathrm{CO}_{3}(1.5 \mathrm{mg}, 10.87 \mu \mathrm{mol})$ were dissolved in water $(50 \mu \mathrm{L})$ and diluted in $150 \mu \mathrm{L}$ of anhydrous $\mathrm{MeCN}$ to form the phase transfer agent. A volume of $200 \mu \mathrm{L}$ of no-carrier-added $\mathrm{H}_{2}{ }^{18} \mathrm{O} /{ }^{18} \mathrm{~F}^{-}$fluoride, obtained from the cyclotron solution, was added to generate the $\left[{ }^{18} \mathrm{~F}\right] \mathrm{KF} / \mathrm{K}_{222}$ complex. Separately, FMISO precursors $(2.5-30 \mathrm{mg}$ ) were dissolved in $300 \mu \mathrm{L}$ of anhydrous $\mathrm{MeCN}$. The $\left[{ }^{18} \mathrm{~F}\right] \mathrm{KF} / \mathrm{K}_{222}$ complex was heated to $105^{\circ} \mathrm{C}$ and held at $105{ }^{\circ} \mathrm{C}$ for $3 \mathrm{~min}$ to evaporate the solvent. Subsequently, one cycle of azeotropic distillation was performed by adding $300 \mu \mathrm{L}$ of $\mathrm{MeCN}$ to the dried residue, and the reaction mixture was heated at $105^{\circ} \mathrm{C}$ for $3 \mathrm{~min}$. A volume of $300 \mu \mathrm{L}$ of FMISO precursors solution (7.43-48 $\mu \mathrm{mol})$ was transferred to the dried $\left[{ }^{18} \mathrm{~F}\right] \mathrm{KF} / \mathrm{K}_{222}$ complex on the reaction site at room temperature. The reaction mixture was stirred at $120^{\circ} \mathrm{C}$ for each time point $(5,10,15$ and $20 \mathrm{~min}$ ) to perform the fluorination reaction. Afterwards, $1 \mathrm{~mL}$ of $1 \mathrm{~mol} \mathrm{~L}^{-1} \mathrm{HCl}$ was added to the crude intermediate product, and the reaction mixture was stirred at $100{ }^{\circ} \mathrm{C}$ for $3 \mathrm{~min}$ for the hydrolysis reaction. After neutralization with $2 \mathrm{~mol} \mathrm{~L}^{-1} \mathrm{NaOH}$, the reaction mixture was purified by radio high performance liquid chromatography (HPLC) with EtOH: $\mathrm{H}_{2} \mathrm{O}=5: 95$. Radioactive thin layer chromatography scanner (AR-2000 radio-TLC imaging scanner, Bioscan, Inc) was used to analyze fluorination efficiency. The TLC plate was developed in a chamber containing 1:3 (v/v) hexane/ethyl acetate solvent mixtures. 


\section{Results and Discussion}

Synthesis of FMISO precursors from 2,2-dimethyl-1,3dioxolane-4-methanol

New $\left[{ }^{18} \mathrm{~F}\right]$ FMISO precursors were prepared for radiosynthesis of the hypoxia marker. As shown in Scheme 1, our first synthetic approach toward $\left[{ }^{18} \mathrm{~F}\right] \mathrm{FMISO}$ precursors started with 2,2-dimethyl-1,3-dioxolane-4methanol, a cheap commercially available material.

The reaction of 2,2-dimethyl-1,3-dioxolane-4-methanol with tosyl chloride and triethylamine in $\mathrm{CH}_{2} \mathrm{Cl}_{2}$ successfully produced compound 2 at $95.9 \%$, and the $\mathrm{S}_{\mathrm{N}} 2$ reaction with 2-nitroimidazole at $110{ }^{\circ} \mathrm{C}$ for $12 \mathrm{~h}$ was then carried out to give compound $3 .{ }^{24}$ Although tosyl group is a good leaving group for nucleophilic substitution reaction, it could be affected by a solution of bases. In this study, we evaluated a variety of reaction conditions such as bases and solvents for the second step, the synthesis of compound $\mathbf{3}$ from compound 2 (Table 1). When 2-nitroimidazole and bases such as $\mathrm{Et}_{3} \mathrm{~N}$ and $\mathrm{K}_{2} \mathrm{CO}_{3}$ were treated with compound 2, the nucleophilic substitution led to low yields. Employment of 1,4-dioxane and toluene for these reactions provided much lower yields ( 0.5 and $3.3 \%$ yield, respectively). However, when DMF was used as a solvent with $\mathrm{Et}_{3} \mathrm{~N}$ and $\mathrm{K}_{2} \mathrm{CO}_{3}$, the incorporation yield of 2-nitroimidazole into the compound 2 was increased. Moreover, the treatment of compound 2 with $\mathrm{Cs}_{2} \mathrm{CO}_{3}$ in DMF resulted in a much higher yield of $82.4 \%$ for nucleophilic substitution.

After examining reaction conditions, the one-pot operation consisted of the tosylation of the primary alcohol, and the nucleophilic reaction with 2-nitroimidazole

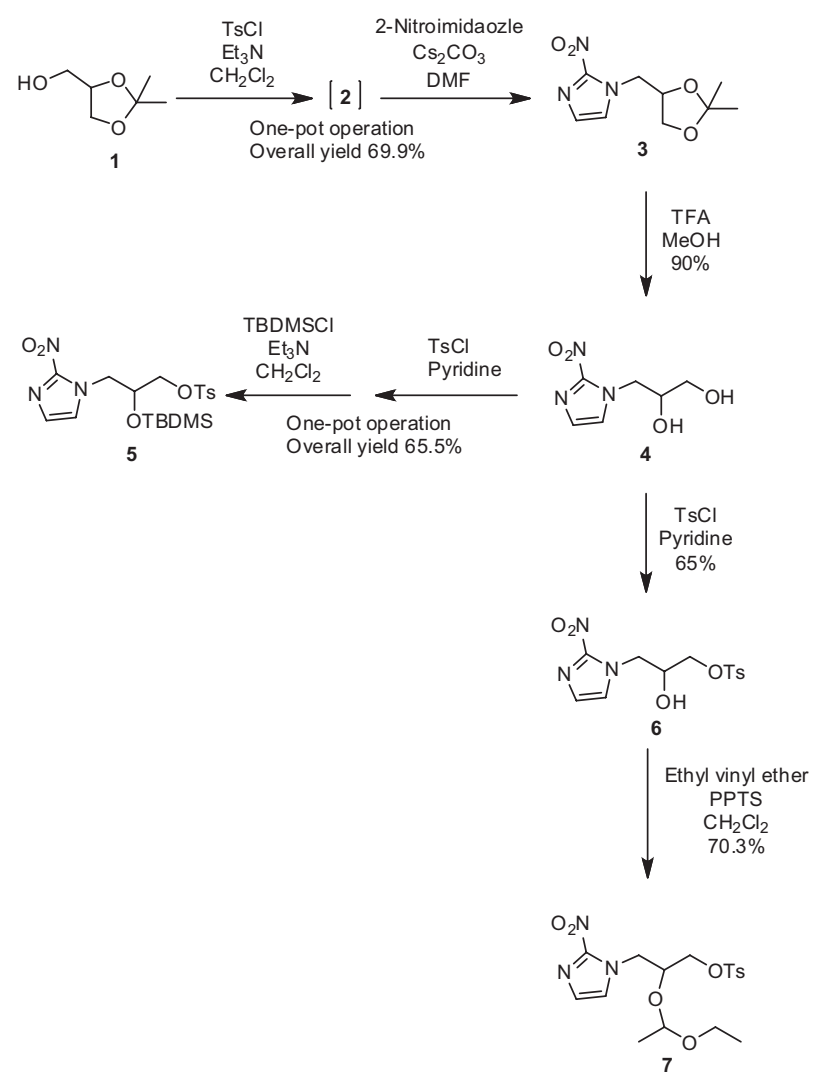

Scheme 1. Synthesis of $\left[{ }^{18} \mathrm{~F}\right]$ FMISO precursors from 2,2-dimethyl-1,3dioxolane-4-methanol.

was carried out for the synthesis of compound $\mathbf{3}$ from 2,2-dimethyl-1,3-dioxolane-4-methanol. The one-pot synthesis successfully resulted in a $69.9 \%$ yield of compound 3. Treatment of compound $\mathbf{3}$ with trifluoroacetic acid in $\mathrm{MeOH}$ at room temperature for $8 \mathrm{~h}$ afforded compound $\mathbf{4}$ at $90 \%$ yield.

Table 1. Optimization of reaction condition

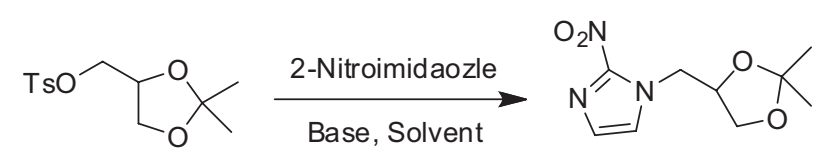

2 3

\begin{tabular}{lccccc}
\hline entry & Base & Solvent & Temperature $/{ }^{\circ} \mathrm{C}$ & Reaction time $/ \mathrm{h}$ & Yield $/ \%$ \\
\hline 1 & $\mathrm{Et}_{3} \mathrm{~N}$ & 1,4 -dioxane & 110 & 12 & 12 \\
2 & $\mathrm{Et}{ }_{3} \mathrm{~N}$ & toluene & 110 & 12 & 13.4 \\
3 & $\mathrm{Et}_{3} \mathrm{~N}$ & DMF & 110 & 12 & 35.3 \\
4 & $\mathrm{~K}_{2} \mathrm{CO}_{3}$ & 1,4 -dioxane & 110 & 12 & 0.5 \\
5 & $\mathrm{~K}_{2} \mathrm{CO}_{3}$ & toluene & 110 & 12 & 3.3 \\
6 & $\mathrm{~K}_{2} \mathrm{CO}_{3}$ & DMF & 110 & 12 & 41.6 \\
7 & $\mathrm{Cs}_{2} \mathrm{CO}_{3}$ & 1,4 -dioxane & 110 & 12 & 2.8 \\
8 & $\mathrm{Cs}_{2} \mathrm{CO}_{3}$ & toluene & 110 & 12 & 0.5 \\
9 & $\mathrm{Cs}_{2} \mathrm{CO}_{3}$ & DMF & 110 & & 82.4 \\
\hline
\end{tabular}

DMF: $N, N$-dimethylformamide 
Desired new FMISO precursors containing tert-butyldimethylsilyl (TBDMS) (compound 5) were successfully obtained by one-pot synthesis of compound 4 that consisted of tosylation and protection of secondary alcohol. Compound $\mathbf{4}$ was subsequently treated with $p$-toluenesulfonyl chloride and anhydrous pyridine at room temperature, and the protection reaction was achieved by using tert-butyldimethylchlorosilane and imidazole in $\mathrm{CH}_{2} \mathrm{Cl}_{2}$ at room temperature for $2 \mathrm{~h}$ for the synthesis of compound $\mathbf{5}$.

We also tried a one-pot sequential operation of compound $\mathbf{4}$ to generate compound $\mathbf{7}$ containing ethoxyethyl (EE) group using the same method. However, the yield of the one-pot synthesis was very low (9\%). Thus, compound 7 was synthesized via 2 separated steps: tosylation ${ }^{24}$ and protection of alcohol using treatment with ethyl vinyl ether and pyridium- $p$-toluenesulfonate in $\mathrm{CH}_{2} \mathrm{Cl}_{2}$. These synthetic approaches resulted in 41.2 and $28.3 \%$ overall yields of compound 5 and 7 from 2,2-dimethyl-1,3dioxolane-4-methanol, respectively.

\section{Radiochemistry}

Feasibility of the approach was tested by radiosynthesis of $\left[{ }^{18} \mathrm{~F}\right] \mathrm{FMISO}$ by the radiolabeling reactions of newly prepared FMISO precursors and a commercial FMISO precursor. $\left[{ }^{18} \mathrm{~F}\right]$ Fluoride ion was prepared through cyclotron operation and then used for the $\left[{ }^{18} \mathrm{~F}\right]$ fluorination reaction that was carried out in the presence of $\mathrm{K}_{2} \mathrm{CO}_{3} / \mathrm{Kryptofix}_{222}$ in $\mathrm{MeCN}$ at $120^{\circ} \mathrm{C}$ for $5,10,15$, and $\left.20 \mathrm{~min} .{ }^{[18} \mathrm{F}\right] \mathrm{FMISO}$, the target product, was obtained through removal of protection groups by the treatment with $\mathrm{HCl}$ in $\mathrm{MeCN}$ at $100{ }^{\circ} \mathrm{C}$ for $5 \mathrm{~min}$, followed by radio HPLC purification (Scheme 2).

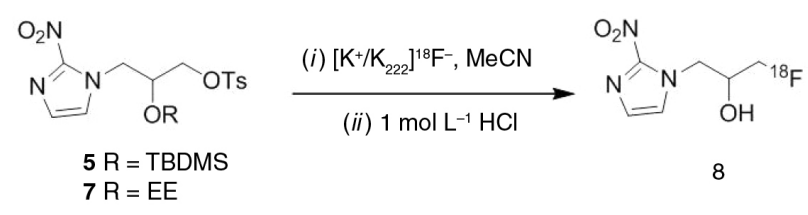

Scheme 2. Radiosynthesis of $\left[{ }^{18} \mathrm{~F}\right] \mathrm{FMISO}$ from new FMISO precursors.

As shown in Table 2, $\left[{ }^{18} \mathrm{~F}\right]$ fluorination reaction of compound 5 containing the TBDMS group showed approximately $12-13 \%$ fluorination yield. This suggested that the generation of the desired product via $\left[{ }^{18} \mathrm{~F}\right]$ fluorination at the tosyl position was prevented by the formation of ${ }^{18} \mathrm{~F}-\mathrm{Si}$ bond. However, compound 7 that has an EE group, underwent $\left[{ }^{18} \mathrm{~F}\right]$ fluorination with a resultant 87 $88 \%$ yield. $\left[{ }^{18} \mathrm{~F}\right]$ Fluorination of 3-(2-nitroimidazol-1-yl)2-O-tetrahydropyranyl-1- $O$-toluenesulfonylpropanediol (NITTP), the widely used commercial precursor for $\left[{ }^{18} \mathrm{~F}\right]$
FMISO, was examined under the same reaction condition as the new FMISO precursors in order to validate the utilization of new FMISO precursors. It turned out that $\left[{ }^{18} \mathrm{~F}\right]$ fluorination of compound $\mathbf{7}$ encouragingly had approximately $20 \%$ higher yield than that of the NITTP precursor (64-71\%), and compound 7 was suitable for $\left[{ }^{18} \mathrm{~F}\right]$ fluorination in the preparation of $\left[{ }^{18} \mathrm{~F}\right] \mathrm{FMISO}$. From the initial screening, compound 7 was selected to perform the further synthesis of $\left[{ }^{18} \mathrm{~F}\right] \mathrm{FMISO}$.

Table 2. $\left[{ }^{18} \mathrm{~F}\right]$ Fluorination yield of FMISO precursors

\begin{tabular}{lcccc}
\hline \multirow{2}{*}{ Precursor } & \multicolumn{4}{c}{$\left[{ }^{18} \mathrm{~F}\right]$ Fluorination efficiency / \% $(\mathrm{n}=3)$} \\
\cline { 2 - 5 } & $5 \mathrm{~min}$ & $10 \mathrm{~min}$ & $15 \mathrm{~min}$ & $20 \mathrm{~min}$ \\
\hline Compound 5 & $12.4 \pm 2.3$ & $13.1 \pm 1.5$ & $13.3 \pm 2.3$ & $13.2 \pm 1.7$ \\
Compound 7 & $87.3 \pm 1.9$ & $88.1 \pm 2.3$ & $87.9 \pm 3.7$ & $88.1 \pm 2.1$ \\
NITTP & $64.1 \pm 3.1$ & $70.6 \pm 2.8$ & $71.2 \pm 2.6$ & $71.3 \pm 2.5$ \\
\hline
\end{tabular}

Reaction condition: compound 7 (7.2 $\mu \mathrm{mol}), \mathrm{K}_{2} \mathrm{CO}_{3}(8.2 \mu \mathrm{mol}), \mathrm{K}_{222}$ $(16.0 \mu \mathrm{mol}), \mathrm{MeCN}(300 \mu \mathrm{L}), 120{ }^{\circ} \mathrm{C}$, radioactivity of $\left[{ }^{18} \mathrm{~F}\right]$ fluoride: $185 \mathrm{MBq}$. NITTP: 3-(2-nitroimidazol-1-yl)-2-O-tetrahydropyranyl-1$O$-toluenesulfonylpropanediol.

Several reaction factors that affect $\left[{ }^{18} \mathrm{~F}\right]$ radiofluorination of compound 7 were investigated for a high radiochemical yield synthesis of $\left[{ }^{18} \mathrm{~F}\right] \mathrm{FMISO}$. First, various bases were explored to identify the optimal $\left[{ }^{18} \mathrm{~F}\right]$ fluorination substitution reactions of compound 7 . The $\left[{ }^{18} \mathrm{~F}\right]$ fluorination reaction was examined at $120{ }^{\circ} \mathrm{C}$ with the precursor$\mathrm{K}_{2} \mathrm{CO}_{3}-\mathrm{K}_{222}$ molar ratio of 1:1.1:2.2. Table 3 indicates that the treatment of compound $\mathbf{7}$ with different bases such as $\mathrm{Cs}_{2} \mathrm{CO}_{3}, \mathrm{CsHCO}_{3}$ and $\mathrm{KHCO}_{3}$ generated slightly different results under the same $\left[{ }^{18} \mathrm{~F}\right]$ fluorination condition as with $\mathrm{K}_{2} \mathrm{CO}_{3}$ when using a fixed amount of compound 7. When $\mathrm{Cs}_{2} \mathrm{CO}_{3}$ and $\mathrm{CsHCO}_{3}$ were employed, $\left[{ }^{18} \mathrm{~F}\right]$ fluorination resulted in a slightly lower efficiency ( 82 and $81 \%$ for 5 min, respectively), while treatment with $\mathrm{KHCO}_{3} / \mathrm{K}_{222}$ provided a similar $\left[{ }^{18} \mathrm{~F}\right]$ fluorination efficiency $(85 \%$ for $5 \mathrm{~min}$ ) to that of the reaction with $\mathrm{K}_{2} \mathrm{CO}_{3} / \mathrm{K}_{222}$. From our results of the base effect on $\left[{ }^{18} \mathrm{~F}\right]$ fluorination, we found that

Table 3. Effect of bases on $\left[{ }^{18} \mathrm{~F}\right]$ fluorination of FMISO precursors

\begin{tabular}{lcccc}
\hline \multirow{2}{*}{ Base } & \multicolumn{4}{c}{$\left[{ }^{18} \mathrm{~F}\right]$ Fluorination efficiency / \% $(\mathrm{n}=3)$} \\
\cline { 2 - 5 } & $5 \mathrm{~min}$ & $10 \mathrm{~min}$ & $15 \mathrm{~min}$ & $20 \mathrm{~min}$ \\
\hline $\mathrm{Cs}_{2} \mathrm{CO}_{3} / \mathrm{K}_{222}$ & $82.6 \pm 2.8$ & $84.7 \pm 2.7$ & $85.2 \pm 2.2$ & $86.9 \pm 2.9$ \\
$\mathrm{CsHCO}_{3} / \mathrm{K}_{222}$ & $81.7 \pm 2.1$ & $84.6 \pm 1.6$ & $85.3 \pm 2.2$ & $85.2 \pm 1.5$ \\
$\mathrm{~K}_{2} \mathrm{CO}_{3} / \mathrm{K}_{222}$ & $87.3 \pm 1.9$ & $88.1 \pm 2.3$ & $87.9 \pm 3.7$ & $88.1 \pm 2.1$ \\
$\mathrm{KHCO}_{3} / \mathrm{K}_{222}$ & $85.2 \pm 1.8$ & $86.6 \pm 1.4$ & $86.5 \pm 2.5$ & $85.8 \pm 2.4$ \\
\hline
\end{tabular}

Reaction condition: compound $7(7.2 \mu \mathrm{mol})$, base $(8.2 \mu \mathrm{mol}), \mathrm{K}_{222}$ $(16.0 \mu \mathrm{mol}), \mathrm{MeCN}(300 \mu \mathrm{L}), 120{ }^{\circ} \mathrm{C}$, radioactivity of $\left[{ }^{18} \mathrm{~F}\right]$ fluoride: $185 \mathrm{MBq} . \mathrm{K}_{222}$ : kryptofix ${ }_{222}$ 
Table 4. Effect of the amount of the base on $\left[{ }^{18} \mathrm{~F}\right]$ fluorination of FMISO precursors

\begin{tabular}{|c|c|c|c|c|c|c|c|}
\hline \multirow{2}{*}{ entry } & \multirow{2}{*}{$\begin{array}{l}\text { Compound } 7 \text { / } \\
\mathrm{mg}(\mu \mathrm{mol})\end{array}$} & \multirow{2}{*}{$\begin{array}{c}\mathrm{K}_{2} \mathrm{CO}_{3} / \\
\mathrm{mg}(\mu \mathrm{mol})\end{array}$} & \multirow{2}{*}{$\begin{array}{c}\mathrm{K}_{222} / \\
\mathrm{mg}(\mu \mathrm{mol})\end{array}$} & \multicolumn{4}{|c|}{$\left[{ }^{18} \mathrm{~F}\right]$ Fluorination efficiency / \% $(\mathrm{n}=3)$} \\
\hline & & & & $5 \mathrm{~min}$ & $10 \mathrm{~min}$ & $15 \min$ & $20 \mathrm{~min}$ \\
\hline 1 & $3(7.2)$ & $0.6(4.4)$ & $3.2(8.52)$ & $84.9 \pm 2.1$ & $86.9 \pm 2.5$ & $87.1 \pm 2.9$ & $87.2 \pm 2.6$ \\
\hline 2 & $3(7.2)$ & $1.1(8.2)$ & $6(16.0)$ & $87.3 \pm 1.9$ & $88.1 \pm 2.3$ & $87.9 \pm 3.7$ & $88.1 \pm 2.1$ \\
\hline 3 & $3(7.2)$ & $1.5(10.9)$ & $8(21.3)$ & $82.1 \pm 2.8$ & $84.5 \pm 4.5$ & $85.1 \pm 2.6$ & $85.2 \pm 2.8$ \\
\hline 4 & $3(7.2)$ & $2.3(16.4)$ & $12(31.9)$ & $72.6 \pm 1.9$ & $73.1 \pm 4.5$ & $72.7 \pm 1.5$ & $67.2 \pm 6.7$ \\
\hline 5 & $3(7.2)$ & $3(21.8)$ & $16(42.6)$ & $60.3 \pm 2.3$ & $61.5 \pm 4.9$ & $63.9 \pm 2.1$ & $59.4 \pm 3.8$ \\
\hline
\end{tabular}

Reaction condition: $\mathrm{MeCN}(300 \mu \mathrm{L}), 120{ }^{\circ} \mathrm{C}$, radioactivity of $\left[{ }^{18} \mathrm{~F}\right]$ fluoride: $185 \mathrm{MBq} . \mathrm{K}_{222}$ : kryptofix ${ }_{222}$.

$\mathrm{K}_{2} \mathrm{CO}_{3}$ and $\mathrm{K}_{222}$ were better $\left[{ }^{18} \mathrm{~F}\right]$ fluorination base reagents than others for $\left[{ }^{18} \mathrm{~F}\right] \mathrm{FMISO}$ radiosynthesis.

To examine the effect of different base amounts on the $\left[{ }^{18} \mathrm{~F}\right]$ fluorination reaction, each compound was treated with various amounts of $\mathrm{K}_{2} \mathrm{CO}_{3} / \mathrm{K}_{222}$ at $120^{\circ} \mathrm{C}$ for $5,10,15$ and $20 \mathrm{~min}$. As shown in Table 4, an increase in the amount of $\mathrm{K}_{2} \mathrm{CO}_{3} / \mathrm{K}_{222}$ to the fixed amount of compound 7 resulted in a decrease in the $\left[{ }^{18} \mathrm{~F}\right]$ fluorination efficiency. When 1:1.1:2.2 ratio of compound $7 / \mathrm{K}_{2} \mathrm{CO}_{3} / \mathrm{K}_{222}$ was used, the fluorination efficiency was $87 \%$ for $5 \mathrm{~min}$. However, an increase in the amount of base $\left(\mathrm{K}_{2} \mathrm{CO}_{3} / \mathrm{K}_{222}\right)$ to 1:3.2:5.9 of compound 7/ $\mathrm{K}_{2} \mathrm{CO}_{3} / \mathrm{K}_{222}$ led to a lower $\left[{ }^{18} \mathrm{~F}\right]$ fluorination efficiency (about $60 \%$ ) for the same reaction time. The result suggests that the $\left[{ }^{18} \mathrm{~F}\right]$ fluorination efficiency was influenced by the molar ratio between compound 7 and the bases, and that $\left[{ }^{18} \mathrm{~F}\right]$ fluorination was prohibited by extra base in the reaction mixture during the reaction. Therefore, $\left[{ }^{18} \mathrm{~F}\right]$ fluorination reaction with near 1:1.1:2.2 molar ratio of compound 7/ $\mathrm{K}_{2} \mathrm{CO}_{3} / \mathrm{K}_{222}$ resulted in higher $\left[{ }^{18} \mathrm{~F}\right]$ fluorination yield by reducing the undesired product formation.

Next, in order to obtain a higher $\left[{ }^{18} \mathrm{~F}\right]$ fluorination yield for the synthesis of $\left[{ }^{18} \mathrm{~F}\right] \mathrm{FMISO}$, temperature effects were examined while keeping the same ratio of compound 7 and bases. We found that there was a correlation between reaction temperature and $\left[{ }^{18} \mathrm{~F}\right]$ fluorination yield. As shown in Table $5,\left[{ }^{18} \mathrm{~F}\right]$ fluorination yield at $130{ }^{\circ} \mathrm{C}$ was $90.6 \%$ within 5 min reaction time. $\left[{ }^{18} \mathrm{~F}\right]$ Fluorination yield at $110^{\circ} \mathrm{C}$

Table 5. $\left[{ }^{18} \mathrm{~F}\right]$ Fluorination yield of FMISO precursors

\begin{tabular}{lcccc}
\hline \multirow{2}{*}{ Temperature $/{ }^{\circ} \mathrm{C}$} & \multicolumn{4}{c}{$\left[{ }^{18} \mathrm{~F}\right]$ Fluorination efficiency / \% $(\mathrm{n}=3)$} \\
\cline { 2 - 5 } & $5 \mathrm{~min}$ & $10 \mathrm{~min}$ & $15 \mathrm{~min}$ & $20 \mathrm{~min}$ \\
\hline 100 & $77.3 \pm 3.6$ & $84.1 \pm 3.3$ & $84.1 \pm 3.3$ & $85.6 \pm 2.7$ \\
110 & $77.8 \pm 3.1$ & $84.7 \pm 2.8$ & $84.8 \pm 2.8$ & $87.5 \pm 2.4$ \\
120 & $87.3 \pm 1.9$ & $88.1 \pm 2.3$ & $87.9 \pm 3.7$ & $88.1 \pm 2.1$ \\
130 & $90.6 \pm 2.5$ & $92.2 \pm 3.2$ & $91.1 \pm 2.7$ & $92.2 \pm 2.2$ \\
\hline
\end{tabular}

Reaction condition: compound 7 (7.2 $\mu \mathrm{mol}), \mathrm{K}_{2} \mathrm{CO}_{3}(8.2 \mu \mathrm{mol}), \mathrm{K}_{222}$ $(16.0 \mu \mathrm{mol}), \mathrm{MeCN}(300 \mu \mathrm{L})$, radioactivity of $\left[{ }^{18} \mathrm{~F}\right]$ fluoride: $185 \mathrm{MBq}$ was not different from that of $100{ }^{\circ} \mathrm{C}(77 \%)$ at the same time. Based on these results, it is clear that temperature is one of critical factors in the substitution reaction.

Higher concentrations of reagents (compound 7 and bases) were also tested to find the optimal reaction conditions. $\left[{ }^{18} \mathrm{~F}\right]$ Fluorination yield using $10 \mathrm{mg}(24 \mu \mathrm{mol})$ and $20 \mathrm{mg}$ ( $48 \mu \mathrm{mol})$ of compound 7 was 91.1 and $93.4 \%$, respectively, within $5 \mathrm{~min}$ reaction time at $120{ }^{\circ} \mathrm{C}$. It suggests that increasing the amount of reagents improved the $\left[{ }^{18} \mathrm{~F}\right]$ fluorination yield, and $\left[{ }^{18} \mathrm{~F}\right]$ fluorination yield of compound 7 was dependent on the amount of precursor.

With the $\left[{ }^{18} \mathrm{~F}\right]$ fluorination reaction conditions in hand, radiosynthesis of $\left[{ }^{18} \mathrm{~F}\right] \mathrm{FMISO}$ from compound $\mathbf{7}$ using a one-pot operation $\left({ }^{18} \mathrm{~F}\right]$ fluorination and hydrolysis) was carried out in a V-shaped reactor. Radiochemical yield and chemical impurities were examined by analytical HPLC chromatogram and radio TLC. The $\left[{ }^{18} \mathrm{~F}\right]$ FMISO prepared in the study was confirmed by HPLC peak comparison with the commercially available reference standard of $\left[{ }^{18} \mathrm{~F}\right]$ FMISO (Figures S13 and S14). Our $\left[{ }^{18} \mathrm{~F}\right]$ FMISO's HPLC peak was consistent with the standard FMISO sample. The $\left[{ }^{18} \mathrm{~F}\right] \mathrm{FMISO}$ product was successfully produced using a reaction within $5 \mathrm{~min}$, and using quantitative hydrolysis of protected $\left[{ }^{18} \mathrm{~F}\right] \mathrm{FMISO}$ within 3 min. Radiosynthesis of $\left[{ }^{18} \mathrm{~F}\right] \mathrm{FMISO}$ from compound 7 resulted in the decay-corrected radiochemical yield of $58 \%$, and a radiochemical purity greater than $99 \%$. The result demonstrated that the new radiosynthesis using new FMISO precursor was a promising method for preparation of $\left[{ }^{18} \mathrm{~F}\right] \mathrm{FMISO}$.

\section{Conclusions}

In summary, novel practical synthetic methods using newly prepared FMISO precursors were developed. These synthetic methods were initiated with (2,2-dimethyl-1,3dioxolan-4-yl)methanol, and included one-pot operations to allow efficient and shorter methods for the preparation of the final compound, $\left[{ }^{18} \mathrm{~F}\right] \mathrm{FMISO}$. Among the newly prepared 
FMISO precursors, compound 7, 2-(1-ethoxyethyl)-3-(2nitro-1 $H$-imidazol-1-yl)propyl 4-methylbenzenesulfonate, showed a higher yield of $\left[{ }^{18} \mathrm{~F}\right]$ fluorination. This synthetic approach might be promising for the facile synthesis of $\left[{ }^{18} \mathrm{~F}\right] \mathrm{FMISO}$ for PET imaging study.

\section{Supplementary Information}

Supplementary data $\left({ }^{1} \mathrm{H}\right.$ and ${ }^{13} \mathrm{C}$ NMR spectra and HPLC data) are available free of charge at http://jbcs.sbq.org.br as PDF file.

\section{Acknowledgments}

This research was supported by Basic Science Research Program through the National Research Foundation of Korea (NRF) funded by the Ministry of Education (2014R1A1A2057943) and research funds of Chonbuk National University in 2013.

\section{References}

1. Hoigebazar, L.; Jeong, J. M.; Lee, J.-Y.; Shetty, D.; Yang, B. Y.; Lee, Y.- S.; Lee, D. S.; Chung, J.-K.; Lee, M. C.; J. Med. Chem. 2012, 55, 3155.

2. Thambi, T.; Deepagan, V. G.; Yoon, H. Y.; Han, H. S.; Kim, S.-H.; Son, S.; Jo, D.-G.; Ahn, C.-H.; Suh, Y. D.; Kim, K.; Kwon, I. C.; Lee, D. S.; Park, J. H.; Biomaterials 2014, 35, 1735.

3. Bonnet, M.; Hong, C. R.; Gu, Y.; Anderson, R. F.; Wilson, W. R.; Pruijn, F. B.; Wang, J.; Hicks, K. O.; Hay, M. P.; Bioorg. Med. Chem. 2014, 22, 2123.

4. Joyard, Y.; Azzouz, R.; Bischoff, L.; Papamicael, C.; Labar, D.; Bol, A.; Bol, V.; Vera, P.; Gregoire, V.; Levacher, V.; Bohn, P.; Bioorg. Med. Chem. 2013, 21, 3680.

5. Okuda, K.; Okabe, Y.; Kadonosono, T.; Ueno, T.; Youssif, B. G. M.; Kizaka-Kondoh, S.; Nagasawa, H.; Bioconjugate Chem. 2012, 23, 324.

6. Mallia, M. B.; Subramanian, S.; Mathur, A.; Sarma, H. D.; Venkatesh, M.; Banerjee, S.; J. Labelled Compd. Radiopharm. 2010, 53, 535 .

7. Mathur, A.; Mallia, M. B.; Banerjee, S.; Sarma, H. D.; Pillai, M. R. A.; Bioorg. Med. Chem. Lett. 2013, 23, 1394.

8. Miller, P. W.; Long, N. J.; Vilar, R.; Gee, A. D.; Angew. Chem., Int. Ed. 2008, 47, 8998.
9. Youssif, B. G. M.; Okuda, K.; Kadonosono, T.; Salem, O. I. A. R.; Hayallah, A. A. M.; Hussein, M. A.; Kizaka-Kondoh, S.; Nagasawa, H.; Chem. Pharm. Bull. 2012, 60, 402.

10. Joyard, Y.; Le Joncour, V.; Castel, H.; Bounana Diouf, C. B.; Bischoff, L.; Papamicael, C.; Levacher, V.; Vera, P.; Bohn, P.; Bioorg. Med. Chem. Lett. 2013, 23, 3704.

11. Kumar, P.; Shustov, G.; Liang, H.; Khlebnikov, V.; Zheng, W.; Yang, X.-H.; Cheeseman, C.; Wiebe, L. I.; J. Med. Chem. 2012, 55, 6033 .

12. Ramalho, T. C.; de Alencastro, R. B.; La-Scalea, M. A.; Figueroa-Villar, J. D.; Biophys. Chem. 2004, 110, 267.

13. Ramalho, T. C.; Franca, T. C. C.; Cortopassi, W. A.; Gonçalves, A. S.; da Silva, A. W. S.; da Cunha, E. F. F.; J. Mol. Struct. 2011, 992, 65.

14. Rojas-Quijano, F. A.; Tircsó, G.; Benyó, E. T.; Baranyai, Z.; Hoang, H. T.; Kálmán, F. K.; Gulaka, P. K.; Kodibagkar, V. D.; Aime, S.; Kovács, Z.; Sherry, A. D.; Chem. - Eur. J. 2012, 18, 9669.

15. Adamsen, T. C. H.; Grierson, J. R.; Krohn, K. A.; J. Labelled Compd. Radiopharm. 2005, 48, 923.

16. Bohn, P.; Deyine, A.; Azzouz, R.; Bailly, L.; Fiol-Petit, C.; Bischoff, L.; Fruit, C.; Marsais, F.; Vera, P.; Nucl. Med. Biol. 2009, 36, 895.

17. Zha, Z.; Zhu, L.; Liu, Y.; Du, F.; Gan, H.; Qiao, J.; Kung, H. F.; Nucl. Med. Biol. 2011, 38, 501.

18. Kumar, P.; Bacchu, V.; Wiebe, L. I.; Semin. Nucl. Med. 2015, $45,122$.

19. Whisenant, J. G.; Peterson, T. E.; Fluckiger, J. U.; Tantawy, M. N.; Ayers, G. D.; Yankeelov, T. E.; Mol. Imaging Biol. 2013, $15,87$.

20. Cheng, J.; Lei, L.; Xu, J.; Sun, Y.; Zhang, Y.; Wang, X.; Pan, L.; Shao, Z.; Zhang, Y.; Liu, G.; J. Nucl. Med. 2013, 54, 333.

21. Riedl, C. C.; Brader, P.; Zanzonico, P.; Reid, V.; Woo, Y.; Wen, B.; Ling, C. C.; Hricak, H.; Fong, Y.; Humm, J. L.; Eur. J. Nucl. Med. Mol. Imaging 2008, 35, 39.

22. Gronroos, T.; Bentzen, L.; Marjamaki, P.; Murata, R.; Horsman, M. R.; Keiding, S.; Eskola, O.; Haaparanta, M.; Minn, H.; Solin, O.; Eur. J. Nucl. Med. Mol. Imaging 2004, 31, 513.

23. Rajendran, J. G.; Mankoff, D. A.; O’Sullivan, F.; Peterson, L. M.; Schwartz, D. L.; Conrad, E. U.; Spence, A. M; Muzi, M.; Farwell, D. G.; Krohn, K. A.; Clin. Cancer Res. 2004, 10, 2245.

24. Nieto, E.; Alajarin, R.; Alvarez-Builla, J.; Larranaga, I.; Gorospe, E.; Pozo, M. A.; Synthesis 2010, 3700.

Submitted: November 2, 2015 Published online: January 20, 2016 